\title{
Exploring the values of the local wisdom of kediri through harinjing and ceker inscription
}

\author{
Ita Kurnia $^{1}$ and Alfi Laila \\ Primary School Teacher Education, Teacher Training and Education Department, Nusantara PGRI University of Kediri, East Java, \\ Indonesia
}

\begin{abstract}
Indonesia needs human resources in sufficient quantity and quality as a major supporter of development. To fulfill these human resources, education has a very important role is character development. One effort that can be done by the people of Kediri as an effort to build Indonesia is to use the values of local wisdom as a force. This values can be explored from Harinjing and Ceker Inscription which is located in Kediri, East Java. This research uses qualitative approach with descriptive method. The research purpose is to explore the potentials of local wisdom of Kediri people through (1) the history of Harinjing Inscription and (2) the history of Ceker Inscription. The results of this research that (1) The construction of embankments and holy buildings on the Serinjing River and the making of irrigation systems in Siman, Kepung, Kediri by Bhagawanta Bari proves that since the time of the kingdom, the people of Kediri have a caring to environmental and social, mutual cooperation, and religious character; (2) The people of Kediri also has the character of love of the homeland and faithful. This is evidenced through the inscriptions in Ceker found in the Sukoanyar, Mojo, Kediri. Key Words: local wisdom, Kediri, Harinjing Inscription, Ceker Inscription.
\end{abstract}

\section{Introduction}

Local Wisdom consists of two words of wisdom and local (KBBI). In general, local wisdom can be interpreted as local ideas that are wise, full of wisdom, good value, which is embedded and followed by members of the community. In the discipline of Anthropology local wisdom known by the term local genius. Local genius is the term first introduced by Quaritch Wales. Many anthropologists are discussing about the mean of local genius, such as Haryati Soebadio who said that local genius is also local identity, identity or cultural personality of the nation that causes the nation is able to absorb and cultivate foreign culture according to the character and ability itself (K.A, Soekarto, 1985:18). While Moendardjito (K.A, Soekarto, 1985:40) said that elements of potential regional culture as local genius because it has proven its ability to survive until now.

Characteristic features local genius is 1) can to survive against the outside culture; 2) has the ability to accommodate elements of external culture; 3 ) have the ability to integrate elements of external culture into indigenous cultures; 4) have the ability to control; And 5) able to give direction to the development of culture. Local wisdom is basically tested naturally and undoubtedly is good because it is a repetitive social action reinforcement. If an action is not considered good by the public, it will automatically not get a continuous reinforcement. The movement naturally occurs voluntarily because it is considered good and contains goodness according to the local community.

Philosophically, local wisdom is a reflection of the cultural behavior of people who have background from the values of life held by the community for generations. For example, in the people of Kediri believes Javanese philosophy such as Urip Iku Urup, Sura Dira Jayaningrat Lebur Dening Pangastuti, Aja Kuminter Mundak Keblinger Aja Cidra Mundak Cilaka, Alon-alon Waton Klakon, Nrimo Ing Pandum, and others will be manifested in living the life of Javanese society. In addition, the philosophical values and order of daily life practices will also affect social life. Examples of life cooperative practiced in the life of the community for generations will inspire the next generation to do the same thing. Potential culture is the potential of local wisdom that needs to be explored and developed in modern society, especially the people of Kediri.

Disclosure of local wisdom values of the people of Kediri is limited to two things. The first is the Harinjing Inscription which is a testament to the success of Bhagawanta Bari in running the farming and irrigation system, thus being awarded tax-exempt land. The second is Ceker Inscription which is a proof of the loyalty of the people of Kediri against the king, so it is rewarded with tax-free land.

1itakurnia@unpkediri.ac.id 
Local wisdom of the people of Kediri must be preserved because culture is not enough just to be told but must be inherited so as not to destroy. The values contained in the local wisdom of the people of Kediri can certainly be integrated into everyday life as one way to preserve local culture and introduce local wisdom to the next generation.

All of this can not be separated from the history of Kediri Regency which is had famous agricultural products since years a go. As one of the evidence is the village of Siman. It is the oldest village located in Kepung, Kediri, East Java. In Siman village there is Harinjing Inscription which is a monument which aims to give appreciation to Bhagawanta Bari who has been instrumental in establishing dawuhan or irrigation system consisting of channel and weir or embankment in Harinjing River (the people of Kediri called Serinjing River).

\section{Method}

This research uses qualitative approach with descriptive method. Qualitative research discloses comprehensively some cases relevant to the purpose of the study (S.E, Robert, 1995) with an eight-month research period beginning in August 2016 until March 2017.

The object of research is Harinjing Inscription and Ceker Inscription. The research was conducted in Siman Village, Kepung, Kediri Regency and Sukoanyar Village, Mojo, Kediri Regency.

Data collection techniques used by conducting participant interviews and documentation, as for the procedure of data analysis techniques using interpretive data analysis by re-checking by participants/member check (F.L, David, 1993).

\section{Results And Discussion}

\subsection{Values of Local Wisdom in Harinjing Inscription}

The people of Kediri knowledge about the environment is wide enough. The interaction between nature and humans can not be separated from the view that humans must be able to adapt to the natural environment, able to manage the natural wealth, and utilize natural wealth wisely. A number of empirical facts mention that some people live and take advantage of the natural wealth it has. The experiences and knowledge people get from the environment make them aware of the kinds of resources they have.

Based from the knowledge, the Siman community, Kepung, Kediri has a tradition of managing a fertile farm. The Siman community has the utmost responsibility to continue the tradition for future generations. The success of agriculture the people of Siman began since the time of Kediri Kingdom. This is evidenced by the existence of Harinjing Inscription.

Inscriptions harpings are carved in andesite stone. According to a report of PV van Stein Callenfels (1334) in De inscriptie van Soekaboemi, this inscription is found in Sukabumi plantations, Kepung, Kediri. It is written using ancient Java characters and languages. The inscription has a length of $75 \mathrm{~cm}$, width $26 \mathrm{~cm}$, and height $117 \mathrm{~cm}$.

According to the sources, a research had once been done by experts of Javanologists such as Prof. MM. Soekarto Karto Atmojo. There is mention of Kediri on three Harinjing Inscriptions which are in Siman, Kepung, Kediri. The inscription consists of three charter written with ancient Javanese script and language on both sides. Here is the transcription of Harinjing Inscription.

\subsubsection{Harinjing A Inscription (25 March $804 A D$ )}

\section{Front Side Inscription (Recto)}

a. Swasti sakawars ātìta 726 Caitra(Selamat tahun saka telah berlalu 726 Bulan Caitra [Maret-April])

b. māsa tithi ekādaśí śuklapaksa wāra ha. wa. so tatkā (tanggal sebelas. paro terang. harinya [Ha]riyang, [Wa]gai, [So]ma/Senin (diekuivalenkan ke masehi menjadi 25 Maret 804 Masehi). Ketika

c. la Bhagawanta Bārī i Culanggi sumaksyakan sīmaniran mula ḍawu(seorang pendeta agung [Bhagawanta] bernama Bārī dari Culanggi menyaksikan [mengudang orang untuk menjadi saksi] penetapan tanah sīmanya [tanah bebas pajak/perdikan] diperoleh dari pembuatan tanggul [ḍ awuhan])

d. han gawainira kali i Hariñjing hana ta 1 maḥ ḍapu bhī sang apatih addibuatlah sungai di Hariñjing adapun tanah milik Dapu Bhī seorang patih tua/sepuh)

e. tuha kāmbah deni kali hinêlyan 1 maḥ satamwah de Bhagawanta Bārī pa(tergenang aliran [air] sungai yang mengalir [seluas] satu tamwah oleh Bhagawanta Bārī)

f. mêgêt sang panggumulan parttaya sang kamalagyan anu hinanākan rika kāla wa (Pemutus perkara bernama Sang Panggumulan, orang kepercayaan bernama Sang Kamalagyan [datang sebagai saksi], serta yang [juga] didatangkan pada waktu itu seorang pejabat) 
g. huta sang labihan pitungtung ḍaman waca panigran ḍaman gundu parwuwus sang apatih dạbernama Sang Labihan, tokoh yang ditinggikan bernama Daman Waca, pembuat kesepakatan [?] bernama Daman Gundu, Juru Bicara bernama Sang Apatih Daman)

h. man gundu winêkas ḍ aman gandhang parwuwus ḍ aman gamêl lawan ḍ aman cali gusti(Gundu, Pemberi Perintah bernama Daman Gandhang, Juru Bicara bernama Daman Gamêl serta Daman Cali, Bangsawan)

i. ḍ apu landap tuhaḍ ihulu ḍ apu gundu .... watan. acur hulêr ḍ apu .... kan apkan ḍ (bernama Dapu Landap, Kepala pimpinan para petugas bernama Dapu Gundu ......watan[?]. petugas pengatur pengairan bernama Dapu ..... kan[?], Petugas pengurus pasar bernama)

j. pu undun hulu kuwu ḍ apu santan wuang atuha sang wulawan lawan ḍ apu patêt tuha wêrêh ḍ amar(Ḍapu Undun, Pimpinan Permukiman bernama Dapu Santan, orang yang dituakan bernama Sang Wulawan dan Dapu Patêt, Pimpinan para pemuda bernama Daman Er)

k. er wariga ḍaman udaya citralekha ḍ apunta waca nāhan sira rāma i paraḍ ah anu hinanākan(Ahli pertanggalan bernama Daman Udaya, Penulis prasasti bernama Dapunta Waca, demikian [juga] para rāma [pimpinan daerah yang terhormat] dari Paradah yang didatangka )

1. rika kāla // rāma i bagu winkas ḍapu tahani gusti ḍapu natu tuhaḍihulu ḍapu garbu wka wuangpada waktu itu // rāma dari Bagu [di antaranya] Penyampai pesan bernama Dapu Tahani, Bangsawan bernama Dapu Natu, Kepala pimpinan para petugas bernama Dapu Garbu, anak-anak muda)

m. matuha saka sang er lāwan ḍ̣ apu tiwul awatas ḍaman wanyaga apêkan ḍaman wahang ....(pengatur hubungan pertemanan bernama Sang Er dan Dapu Tiwul, Petugas penentu batas tanah bernama Daman Wanyaga, Petugas Pasar bernama Daman Wahang ..... )

n. tu ḍaman sampanna parwuwus sang majalu bsi lāwan ḍaman bangun wariga ḍapu taji tuha wêrêh daman dahara (tu [?] bernama Daman Sampanna, Juru bicara bernama Sang Majalu Bsi dan Ḍaman Bangun, Ahli pertanggalan bernama Dapu Taji, Pimpinan para pemuda bernama Daman Dahara)

o. ni tuha buru ḍaman kuñja tuhalas ḍaman wacana lāwan ḍaman wihar tuha kalang ḍaman wanułPengawas perburuan bernama Daman Kuñja, Pengawas hutan bernama Daman Wacana dan Daman Wihar, Pemimpin golongan kalang [mungkin tukang kayu atau pembuat bangunan] bernama Daman Wanua)

p. parwuwus ḍaman lampuyang wadahuma ḍaman waca tuha padahi si bunta lāwan si kāryya kulapati i(Juru Bicara bernama Daman Lampuyang, Pengatur masalah rumah tangga bernama Daman Waca, Pimpinan pemain gendang bernama Si Bunta dan Si Karyya, tokoh masyarakat dari )

q. Hariñjing ḍapunta manḍi kulapati i lalatêng ḍapu aman kulapati i bubul dapunta karugnan tp siring anung (Hariñjing bernama Dapunta Manḍi, tokoh masyarakat dari Lalatêng bernama Dapu Aman, tokoh masyarakat dari Bubul bernama Dapunta Karugnan, dari daerah batas wilayah yang menjadi)

r. sākș i ḍaman guntar i garaga ḍ aman damên nāhan sira. aligrama sakṣ inira saks yakên ikana sīmanira mul(\$aksi bernama Daman Guntar, dari daerah Garaga bernama Daman Damên itulah semuanya. Orang-orang yang telah datang menjadi saksi untuk melihat secara langsung penetapan status sīma-nya [Bhagawanta Bārī] yang diperoleh dari pembuatan)

s. ḍawuhan // kunang tinaḍah bhagawanta i ramanta gawai sang aswa syamah (?) warangan pitu, kawêrêhan inuman (tanggul [ḍ awuhan] // Adapun yang diterima oleh Bhagawanta dari para pimpinan wilayah yang paling terhormat membuat selera makan menjadi nikmat, hidangan sayur-sayuran syamah [?] untuk berpesta ria tujuh minuman yang bisa membuat awet muda [kuat])

t. amunuhatasamada (?) awaknira sira kunang yan gawai i sabya .... salwiranira // niyanta wr ddhinira mu. an. sang pa (menaruh perhatian terhadap tubuh beliau apabila mengerjakan sesuatu yang pantas dilakukan ..... segala macam // benar-benar sebuah kemajuan [daerah] yang dikerjakan beliau [Bhagawanta Bārī] beserta Sang pemutus perkara)

u. mgat lasun deni .... bhagawanta ḍapu lanḍ ap .... anta ... an ...(berasal dari Lasun oleh ... Bhagawanta, Dapu Land ap .... anta ..... an ...).

v. ̣̣ apu hadyan ḍ apu sūra ḍ aman kuñja panigran sang taruk ramānta ri tajam wina ... sangka. i. sang arawisa(Ḍapu Hadyan, Ḍapu Sūra, Daman Kuñja, pembuat kesepakatan [?] bernama Sang Taruk, Pimpinan wilayah yang terhormat dari Tajam wina[?].... sangka[?]. dari Sang Arawisa)

w. i sangkawu i sangkāra i sang ... i sangsala i sangngang nāhan kawr ddhini gawe Bhagawanta i(di Sangkawu, di Sangkāra, di Sang ... di Sangsala, di Sangngang, itulah sebuah kemajuan [daerah] yang dilakukan oleh Bhagawanta dari)

x. Culanggi //-// ... i bagu i kukap i watu walu (Culanggi //-// ... di Bagu, di Kukap, di Watu Walu)

y. .... ralan tpisiringnya watêk (... daerah perbatasan wilayah)

\section{Right Side Inscription}

a. Rangga manggêhan tangkilsugih rạ̣ da(Rangga, Manggêhan, Tangkilsugih, Rạ̣ damman)

b. mman nahan sakweh nikang wanua ka (itulah semua desa yang diikutsertakan)

c. samwahan deni gawai Bhagawanta Bārī (dalam pekerjaan [yang dilakukan oleh] Bhagawanta Bārī) 


\subsubsection{Harinjing $B$ Inscription (19 September 921 AD)}

a. // Swasti śakawarș âtīta 843(Selamat tahun saka telah berlalu 843)

b. aśujimāsa tithi pañcadasi śuklapaksa wāra ha. u. (Bulan Asuji [september-oktober]. tanggal limabelas. Paro terang. Harinya [Ha]riyang, [U]manis/legi)

c. bu nakṣatra uttarabhadrawāda ahnibudhna dewāta wṛ sayoga ta([Bu]dha/Rabu (diekuivalenkan ke masehi menjadi 19 September 921 Masehi). Pada perbintangan terletak pada uttarabhadrawāda. Penguasa waktu terletak pada Waktu selama gerak bersamaan antara bulan dan matahari dalam posisi $13^{\circ} 20^{\prime}$ terletak padawr sa)

d. tkala ajña Śrī Mahārāja Rake Layang Dyah Tuloḍ ong tinadah rakryan(ketika perintah dari Śrī Mahārāja Rake Layang Dyah Tuloḍ ong diterima oleh Rakryan)

e. mapatih i hino mahāmantri śrī ketudharamanimantaprabhāprabhusaktitri (Mapatih i Hino Mahāmantri Śr̄̄ Ketudharamanimantaprabhāprabhusaktitri)

f. wikrama umingsor ing rakryan mapatih halu wka sirikan kalungwarak tiruan muang (wirama kemudian diturunkan kembali kepada [pejabat tinggi istana yaitu] Rakryan, Mapatih dari daerah Halu, Wka, Sirikan, Kalungwarak, Tiruan dan)

g. pamgat bawang tiruan halaran kumonnakan saș ana sang dewata lumah i kwak ka(pemberi keputusan [terdiri dari] Bawang, Tiruan, Halaran memerintahkan surat perintah dari almarhum yang dicandikan di Kwak)

h. pagêhakna ni wka Bhagawanta Bārī sang magawai kali i Hariñjing ikanang tan kolāhala (untuk diperkuat kembali oleh anak Bhagawanta Bārī seorang tokoh yang telah membuat sungai di Hariñjing [agar] tidak diganggu gugat)

i. deni patih wahuta rāma muang tan katamāna dening saprakāra ni mangilāla dṛ byahaji(oleh [pejabat istana terdiri dari] Patih, Wahuta, Rāma serta tidak didatangi oleh para abdi dalem istana [mangilāla dṛ byahaji)

j. kring paụammapuy tapahaji erhaji tuhān tuha dagang tuhā huñjamman manghuri kutak ka([di antaranya] petugas pemadam kebakaran, penjaga tempat pertapaan milik raja [?], Penjaga air milik raja, para pimpinan, ketua perdagangan, ketua kelompok masyarakat, juru tulis di istana, Pemukul)

k. payungngan pakalangkang pamanikan limus galuh pengaruhan manimpiki malañjang lba kalungwa (Petugas Pembawa Payung [?], Pekerja Bangunan Kayu [?], Pembuat Manik-manik, Pembuat Perhiasan Emas, Tukang Emas, Tukang Ukir, Pengawas Perjudian, Asisten Pengawas Perjudian, Kalungwarak [?],)

1. rak wungkal tajam paranakan kḍi walyan widu mangidung singgah mamr si hulun haji wata(Tukang Mempertajam Batu, para anak buah dari dukun wanita, dukun laki-laki, Biduan, Singgah [?], Pejabat Keagamaan, Pelayan Raja, [golongan] yang tinggal di)

m. k i jro ityewamādi saprakāra ni mangilala dṛ byahaji miśra paramiśra tan tamātah i(dalam [keraton] dan selanjutnya seluruh abdi dalem istana [mangilala dṛ byahaji] [khususnya] pemungut pajak usaha kerajinan tidak ingkar [memasuki])

n. sthā ni wka Bhagawanta Bārī i Culanggi sang girigil muang ikāng kabikuan mula sa .... mā ma (daerah tempat tinggal para anak Bhagawanta Bārī di Culanggi, Sang Girigil dan sebuah bangunan suci untuk para wiku [bhiksu] ...mā ma [?])

o. kangaran i wulahya ing waruk ing śambung ing wilang kewala pamasangnya mās su 1 maparah. (bernama di Wulahya, di Waruk, di Śambung, di Wilang hanya memasang [membayar] emas 1 suwarṇ a diberikan) ... until

w. praśasti sāṣ ana śrī mahārāja //-//(dalam prasasti perintah śrī mahārāja)

\subsubsection{Harinjing C Inscription (7 March 927 AD)}

a. muwah śaka 849 caitramasa tithī pratipāda śukla (serta tahun saka 849 Bulan Caitra [Maret-April] Tanggal pertama paro terang)

b. wara wā. u. bu. Tatkala ni wka Bhagawanta Bārī mintonakan anugraha sang lumāh ri kwa (Harinya [wā]s, [u]manis, [bu]dha/rabu(diekuivalenkan ke masehi menjadi 7 Maret 927 Masehi). Ketika para anak [keturunan] Bhagawanta Bārī memperlihatkan sebuah anugerah dari almarhum yang dicandikan di Kwak)

c. k tinaḍah rake hino mpu ketu makasambandha pakon sang pamgat momahhumah kaka (diterima oleh Rakai Hino Mpu Ketu sebagai alasannya yaitu perintah dari Sang Pemutus Perkara tentang urusan perumahan kakak)

d. n rake sumba sang pamgat anggêhan sang parpāt sira ta kumonnakan ikang prasasti umnahhakna ya wung (dari Rakai Sumba, Sang Pemutus Perkara tentang hubungan seseorang bernama Sang Parpāt, mereka memerintahkan agar prasasti dipahatkan pada batu)

e. kal kweh ni wka Bhagawanta Bārī i Culanggi sang giwil sang trayi sang saśrā sang pulas ri wilang sang banat (semua anak keturunan Bhagawanta Bārī dari Culanggi [di antaranya] Sang Giwil, Sang Trayi, Sang Saśrā, Sang Pulas di Wilang, Sang Banat) 
f. sang durak ring sambung sang ngrawit sang uwir ri wulahya sang wasêh sang bayakā ri waruk sang wadhi sang kinang nāhan (Sang Durak di Sambung, Sang Ngrawit, Sang Uwir di Wulahya, Sang Wasêh, Sang Bayakā di Waruk, Sang Wadhi, Sang Kinang. Itulah [nama-nama]).

\section{Left Side Inscription}

a. kwehnira wka Bhagawanta Bārī umanhhakan nikang (semua anak keturunan Bhagawanta Bārī yang [meminta untuk] menuliskan)

b. prasasti ri wungkal kunang ta kweh (?) sang lumah ri kwa (prasasti di batu. Demikian pula sang tokoh yang dicandikan di Kwak)

c. $\quad \mathrm{k}$ asing umulahhulaha ikang anugraha sangyang su (?) (siapapunn yang berani mengganggu gugat anugerah sang hyang su [?])

d. $\quad$ kram (?) upadrawa yan .... kuha ... jnā..... (kram [?] akan mendapat bencana apabila..... kuha [?].... jnā.......)

e. $\quad \quad \ldots \ldots \ldots \ldots \ldots \ldots . / / / /(\ldots \ldots \ldots \ldots \ldots \ldots \ldots \ldots)$.

(Casparis (1978) dalam Annisa, 2011; K.A, Soekarto, 1985:49-63; and J.Z, Petrus, 1982)

Harinjing A Inscription dated March 25, $804 \mathrm{AD}$, tells of a prominent priest (Bhagawanta) named Bari who built the embankment along with the river in Harinjing by bringing in some official figures as witnesses. The year is the reign of Rakai Warak Dyah Wanara who ascended the throne of Mḍ ang Kingdom (Ancient Mataram) in 803 AD (K.A, Soekarto, 1985:78).

Harinjing B Inscription Dated September 19, 921 AD, recounts the reinforcement of Bhagawanta Bari's land grant status (Perdikan) by King Rakai Layang Dyah Tulodong and given to the offspring of Bhagawanta Bari. The Harinjing Inscription $\mathrm{C}$ dates from March 7, $927 \mathrm{AD}$, tells the inscription to be a legitimate decree of the king and presumably when it is still written on a rontal (Ripta Inscription) or metal plate (Tamra Inscription) to be written on a stone. In the year 921 and 297 AD was the reign of Rakai Layang Dyah Tulodong in the Kingdom of Md ang (Ancient Mataram) (about 919-927 AD) (S.H, Endang, et al, 2010:178 \&182).

On lines 1 to 23 the Harinjing B Inscription states that Sri Maharaja Rake Layang Dyah Tulodong on 15 Suklapaksa month of Asuji in 843 Saka (19 September 921 AD) acknowledged the rights of pastors in Culanggi because they still have to maintain Harinjing channel.

Starting the next line, line 24 to last, this inscription states that a similar right is recognized at 1 Suklapaksa Caitra month of 849 Saka (June 7, 1015 AD). The contents of the three Harinjing Inscriptions are figures from the village of Culanggi named Bhagawanta Bari who received a land grant from Sri Maharaja Rake Layang Dyah Tulodong. The success of Bagawanta Bhari at that time, the effort to save the environment from the raging annual floods that threaten the region.

Based on the information in Harijing C Inscription can be seen that slate Harbing Inscription which is currently a collection of National Museum-Jakarta (inventory number D-173) was written on March 7, 927 AD.

Since then Kediri began to be mentioned as a country or kingdom because it is an independent region with a lot of farming. In Harinjing Inscription also mentioned the construction of irrigation system (which consists of channels and embankments) called dawuhan in Konto River, namely Harinjing River. Soil fertility around Brantas river caused by volcanic material deposits from some active volcano in the upstream of the river, namely Mount Kelud and Mount Semeru.

The story of Bhagawanta Bari as it is written in the Harinjing Inscription is full of positive values that should be exemplified by the whole society, especially Kediri people. Efforts to construct embankments to cope with floods are exemplary in order to foster environmental and social concerns.

In addition Bhagawanta Bari's attitude of building a holy building (dharma) around the Harinjing River which was later reinforced by his offspring, is highly relevant to religious values, ie obedient behavior of religious teachings adopted, tolerant of the implementation of other religious services, and living in harmony with followers of other religions (H.H, Said, et al, 2010:9-10). The values of local wisdom like this are very important to be passed on to the young generation today.

Bhagawanta Bari figure is a human figure who has a caring soul, high mutual cooperation, and religious. Three things that are reflected and easily understood and recognized to date.

a. Caring, both care about the environment and social. This attitude was shown by Bhagawanta Bari through building a embankment (irrigation canal) to overcome the flood disaster that occurred at the time.

b. Mutual cooperation, can be called working together is a value that is rooted in Javanese culture. The value of mutual cooperation is a basic value that can create a social network that serves to solve daily problems faced, namely working together to create a embankment (irrigation canal).

c. Religious. Local wisdom of Javanese is born, lived, and developed. Javanese culture manifested in various forms of representation either in the form of ideas, thoughts, moral/spiritual teachings, philosophical teachings as well as ideas and concepts of leadership and society. Religious values can be seen from the establishment of a holy building around the Harinjing river by Bhagawanta Bari. 


\subsection{Values of Local Wisdom in Ceker Inscription}

Unlike the Harinjing Inscription, not much can be showed in the Inscription of Ceker. Ceker Inscription originating from Sukoanyar Village, Mojo, Kediri Regency from 1107 Saka (September 11, 1185 AD).

The inscription was made by Paduka Sri Maharaja Sri Kameswara Triwikramawatara Aniwaryyawiryya Parakrama Digjayotunggadewanama. The inscription was once declared missing (K.A, Soekarto, 1985:72). But later the Ceker Inscription known stored in the Museum Airlangga Kediri.

The inscription contains the story of the people of Ceker (duwan i Ckêr) came to the king and told him that he had received the grace from the previous ruler of the perdikan land. They asked that the inscription be asked to be strengthened or written on a stone. Furthermore, it is also told about the story that Sri Maharaja who returned to his position in Bhumi Kadiri (mantuk ri sīmanira ring Bhūmi Kadiri), thus raising the allegation that the event was related to the enemy's attack, so the king had to leave his palace (S.H, Endang, et al, 2010:292). Attitudes made by residents of Ceker (now Sukoanyar village) is relevant to the value of love of the homeland in the concept of cultural education and character of the nation.

Regarding the figure of Sri Maharaja Sri Kameswara once alleged by Prof. Dr. R.M.Ng. Poerbatjaraka as the character of Panji Inu Kertapati in the script of Panji Story. If there is a Panji Inu Kertapati name that has the wife of Goddess Candrakirana, while in Kakawin Smaradahana composed by Mpu Dharmaja during the reign Sri Maharaja Sri Kameswara, the king has a wife named Sri Kiranaratu (Poerbatjaraka, 1986:XI).

But this opinion is still causing debate among experts. More interesting again in Kakawin Smaradahana, it turns out Mpu Dharmaja in the manggala (opening) states that Sri Maharaja Sri Kameswara also as Panji. The complete quote is as follows, "yan rin் pran் kita sinha wīra taruṇ ājjāpañji śüreṅraṇ a",meaning that in the battlefield you are like a brave lion, young and handsome named Panji Surengran a (Manu, 1986).

The value of local wisdom that can be exemplary in Ceker Inscription is the love of the homeland and faithful. Because of the love and loyalty to the king, the people of Ceker get a land grant. This value is exemplary by the young generation in the middle of the moral gradation of children of the nation that is currently happening.

\section{Cover}

\subsection{Conclusion}

Referring to the findings of research and discussion on the values of local wisdom Kediri as an effort to preserve the culture of the nation, it can be concluded as follows:

a. The construction of embankments and holy buildings on the Serinjing River and the making of irrigation systems in Siman, Kepung, Kediri by Bhagawanta Bari proves that since the time of the kingdom, the people of Kediri have a caring to environmental and social, mutual cooperation, and religious.

b. The people of Kediri also has the character of love of the homeland and faithful. This is evidenced through the inscriptions in Ceker found in the Sukoanyar, Mojo, Kediri.

\subsection{Acknowledgement}

After exploring the potentials of local wisdom of the people of Kediri through the history of Harinjing Inscription and the history of Ceker Inscription located in Kepung and Mojo district, it is found that since the time of Kediri Kingdom have some values of character that should be emulated by the young generation today. These character values are among the environmental and social attitudes, the mutual cooperation, and the religious as they are written in the Harinjing Inscription.

Ceker Inscription also have the value of the love character of the homeland and faithful. But it is unfortunate considering the people of Kediri today not many people know the existence as well as exemplary values of the inscription. It is a duty for local governments and researchers and culturalists to work together to uncover this "treasure" in order to create a society of character as it has been abandoned by its predecessors.

\section{References}

Annisa, Penggunaan kronogram di Indonesia,Vietnam, dan Kamboja abad VII-XIV M: pendekatan arkeologis dan epigrafis (Tesis tidak diterbitkan, Fakultas Ilmu Budaya UI, Depok, 2011)

F.L, David, Qualitative research in education, an introduction to the major tradition (Longman, New York, 1993)

H.H, Said, et al, Bahan pelatihan: penguatan metodologi pembelajaran berdasarkan nilai-nilai budaya untuk membentuk daya saing dan karakter bangsa (Badan Penelitian dan Pengembangan Pusat Kurikulum, Jakarta, 2010) 
J.Z, Petrus, Kalangwan: sastra Jawa kuno selayang panjang. Terjemahan Dick Handoko S.J. 1985 (Djambatan, Jakarta, 1974)

J.Z, Petrus, Kamus Jawa Kuna Indonesia. Terjemahan Darusuprapta \& Sumarti S. 1994 (Gramedia Pustaka Utama, Jakarta, 1982)

K.A, Soekarto, Hari jadi Kediri (Lembaga Javanologi, Yogyakarta, 1985)

M, Pidarta, Landasan kependidikan: stimulus ilmu pendidikan bercorak Indonesia (Rineka Cipta, Jakarta, 2007)

Manu, Kakawin smaradahana: sebuah studi filologi dalam rangka ilmu sastra (Skripsi tidak diterbitkan, Fakultas Sastra Universitas Gajah Mada, Yogyakarta, 1985)

N.W, Sartini, Jurnal filsafat 37 (2), 111-120 (2004). Dapat diunduh di: http://scholar.google.co.id/citations? $\underline{\text { user }=n z Q p U l c A A A A J \& h l=\mathrm{id}}$

Poerbatjaraka, Tjerita pandji dalam perbandingan (Gunung Agung, Djakarta, 1986)

S, Muchlas dan Hariyanto, Konsep dan model pendidikan karakter (Remaja Rosdakarya, Bandung, 2012)

S.E, Robert, The art of case study research (Sage Publications, Thousand Oaks, CA,1995)

S.H, Endang, et al, Zaman kuno. Dalam sejarah nasional Indonesia II (Balai Pustaka, Jakarta, 2010)

S.S, Nana, Metode penelitian pendidikan (Remaja Rosdakarya, Bandung, 2005)

Suhartini, Prosiding seminar nasional penelitian, pendidikan, dan penerapan MIPA (Yogyakarta, 2009). Dapat diunduh di: http://eprints.uny.ac.id/12149/1/Bio Suhartini2\%20UNY.pdf

Tim Penyusun, Kamus Besar Bahasa Indonesia (Pusat Bahasa, Jakarta, 2008)

---. Kebudayaan Jawa (Gajah Mada University Press, Yogyakarta, 1984)

---. Penduduk Kabupaten Kediri (BPS, Jakarta, 2015)

---. Buku kearifan lokal di tengah modernisasi. pusat penelitian dan pengembangan kebudayaan badan pengembangan sumber daya kebudayaan dan pariwisata Kementerian Kebudayaan dan Pariwisata Republik Indonesia (Kementerian Kebudayaan dan Pariwisata Republik Indonesia, Jakarta, 2011) 